\title{
THE GLOBAL GEOSCIENCE TRANSECTS PROJECT IN FINLAND
}

\author{
K. KORSMAN and T. KORJA
}

\begin{abstract}
KORSMAN, K. and KORJA, T. 1999. The Global Geoscience Transects Project in Finland. Bulletin of the Geological Society of Finland 71, Part 1, 5-12.

K. Korsman and T. Korja: Geological Survey of Finland, P.O. Box 96, FIN02151 Espoo, Finland.

E-mail: toivo.korja@gsf.fi
\end{abstract}

An international Global Geoscience Transects (GGT) Project was initiated in 1985 with the primary goal of integrating surface geological data with subsurface geophysical data to enhance our understanding of crustal structure from a variety of active and ancient tectonic environments (Goetze \& Monger 1992). The international GGT Project, which was completed at the end of 1998 , has been a collaborative venture of the International Lithosphere Program (ILP) established by the International Union of Geological Sciences (IUGS) and the International Union of Geodesy and Geophysics (IUGG). Its goal was to construct lithospheric transects, mainly crustal cross sections through crucial geologic and tectonic features, such as mountain belts, grabens, sedimentary basins, and hazardous regions prone to the disastrous activities of earthquakes and volcanoes, in order to allow direct comparisons. All of the available data have been assembled at an equal scale of 1:1 million in order to enable global comparisons of similar structures as well as to display the nature and evolution of the Earth's lithosphere. Transects typically consist of strip maps that portray geological and geophysical data covering a region at least $100 \mathrm{~km}$ in width and variable in length. The subsurface crustal sections include geologic and tectonic interpretations with observed and calculated geophysical anomalies. Data such as geochemical, geodetic, borehole, earthquakes, electrical resistivity, heat flow, and seismic reflection or refraction are presented where available. The first transect compilations were published by the ILP and American Geophysical Union (AGU) in August, 1991. Since then the digitization guidelines were developed (Goetze \& Williams 1993) and in 1995 ILP decided that future transects will be available only as digital products (see GGT homepage at http://quake.wr.usgs.gov/GGT).

The studies along the SVEKA profile form a Finnish contribution to the GGT Project (Korja \& Korsman 1993). The GGT/SVEKA transect, which contains the most comprehensive geological, geochemical and geophysical data available for Finland, is located in the central part of the Fennoscandian Shield. It crosses the main tectonic units in southern and central Finland and covers an area $160 \mathrm{~km}$ wide and $840 \mathrm{~km}$ long extending from near the Finnish-Russian border in the northeast to the Finnish-Swedish border within the Alland archipelago in the southwest (Figs. 1 and 2). In the northeast, the transect traverses across 


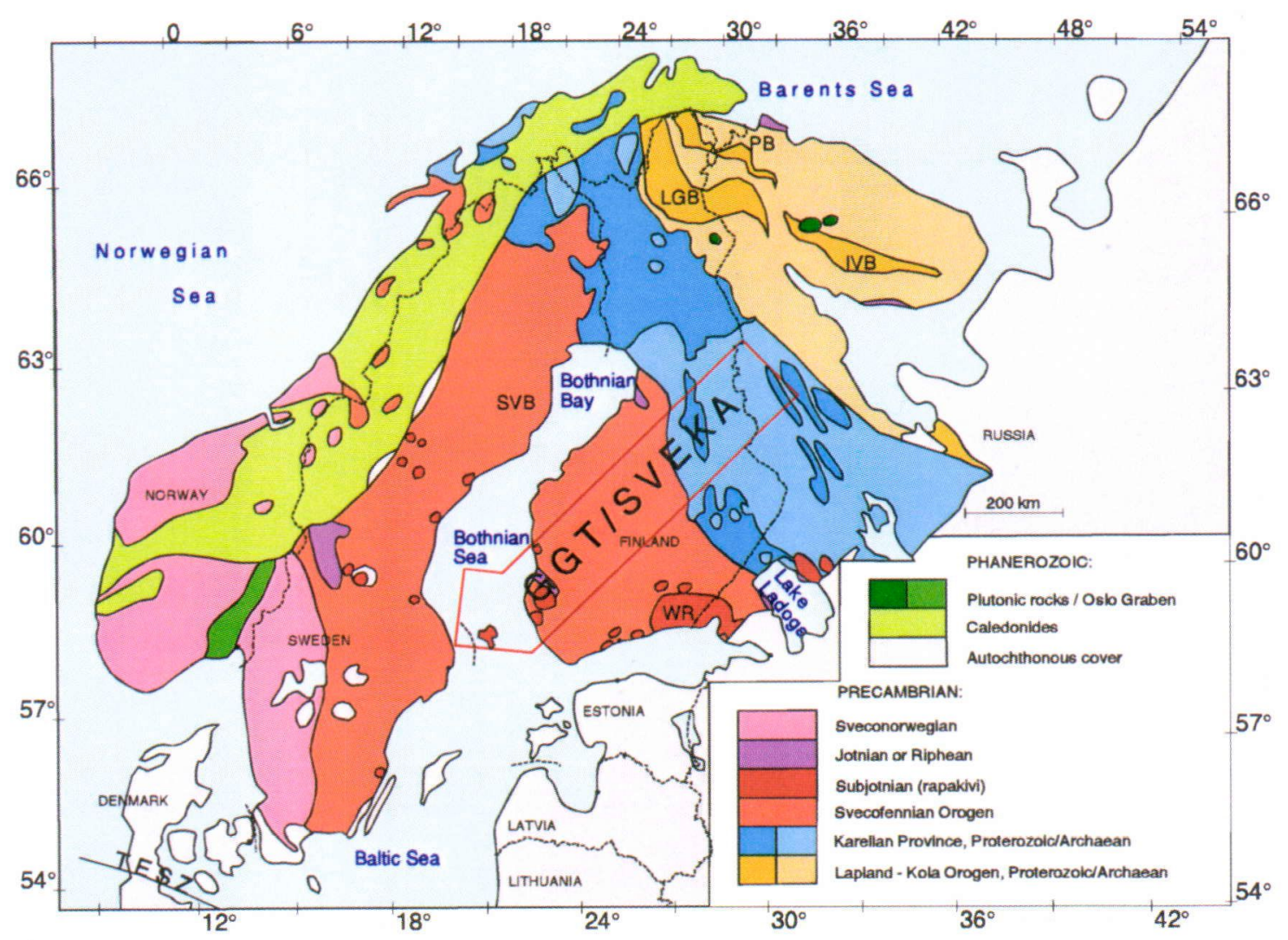

Fig. 1. Main geotectonic units in the Fennoscandian Shield. IVB - Imandra-Varzuga Belt, LGB - Lapland Granulite Belt, PB - Pechenga Belt, SVB - Skellefteå Volcanic Belt, TESZ - Trans-European Suture Zone, and WR Wiborg Rapakivi. The GGT/SVEKA transect is outlined by a polygon.

the western part of the Karelian Province, which includes e.g. the Archaean Kuhmo Greenstone Belt and the Palaeoproterozoic Jormua Ophiolite Complex, and crosses the boundary zone between the Karelian Province and the Palaeoproterozoic Svecofennian Orogen. Further to the southwest, the transect traverses across the northern and central part of the Svecofennian Orogen including, from the northeast to the southwest, the Pyhäsalmi Primitive Island Arc, the Central Finland Continental Arc, and the Southern Finland Sedimentary-Volcanic Complex. The transect ends in an area of Mesoproterozoic rocks, which includes rapakivi granites, Subjotnian diabase dykes, and Jotnian sandstones. The geological evolution started $3.2 \mathrm{Ga}$ ago in the eastern part of the transect and is rejuvenating gradually to the southwest, the youngest rocks being the $1.2 \mathrm{Ga}$ old Subjotnian diabase dykes as well as the minor occurrences of Neoproterozoic sedimentary rocks. The transect is therefore ideally situated for studying the Svecofennian orogeny and its effects in the Archaean Karelian crust as well as the later, mainly Subjotnian, extension of the Svecofennian crust.

The GGT/SVEKA program, following the objectives of the international GGT program, has been aimed at constructing a tectono-evolutionary model of the crust along a transect with special emphasis on the crustal thickness variations, the high metamorphic temperatures associated with the Svecofennian orogeny, the significance of deep crustal conductors, and the effects of the Sve- 
Fig. 2. Geotectonic units in southern and central Finland. The GGT/ SVEKA transect is outlined by a polygon.
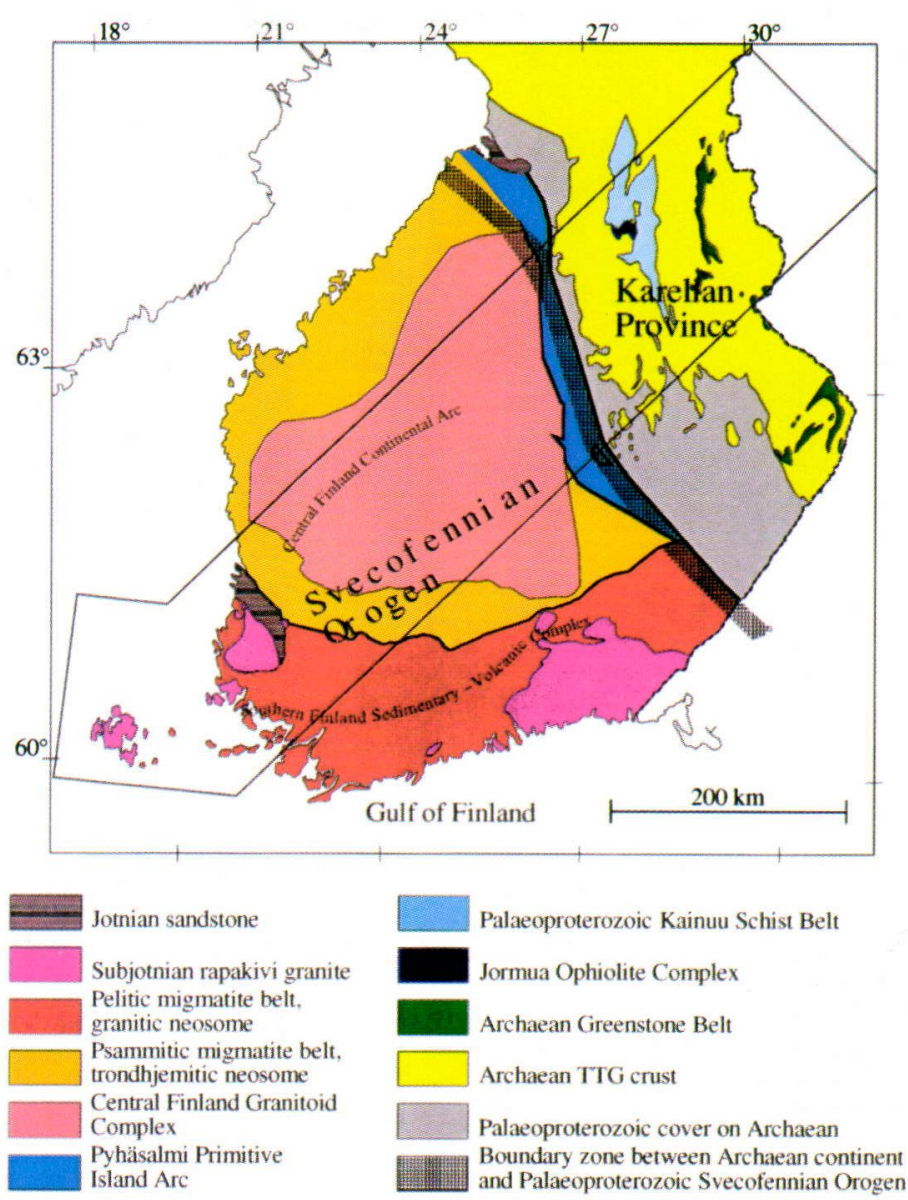

cofennian orogeny in the Archaean Karelian Province (Fig. 3). Much attention has been given to understand the temporal and causal relationships between deformation, metamorphism, and magmatism because this is a necessary step for understanding the evolution of a tectonically thickened crust metamorphosed under high-T/low-P conditions.

The Svecofennides have a complex evolution that varies in space and time in detail. Many coeval, overlapping and continuous processes have resulted in a unique crust rich in geophysical and geological details (see e.g. Korsman et al. 1999). The major findings of the GGT/SVEKA work, based on geophysical and geological observations, can be summarized by the following features char- acterizing the Svecofennian crust, its evolution, and its geophysical and geological properties:

1 - Seismic data indicate remarkable variations from $27 \mathrm{~km}$ to $65 \mathrm{~km}$ in the crustal thickness of the Precambrian crust in Fennoscandia but most of the variations in Moho depth can be explained by variations in the thickness of the high-velocity lower crust which ranges from 0 to $30 \mathrm{~km}$.

2 - The crustal thickness variations, which have a bimodal distribution in Fennoscandia, are mostly compensated within the crust by density variations. Thinner crust (dominant crustal thickness in average $45 \mathrm{~km}$ ) is found in regions that have experienced one or several anorogenic extensional events (e.g. the Archaean Karelian Province and the Subjotnian rapakivi areas), whereas large parts 

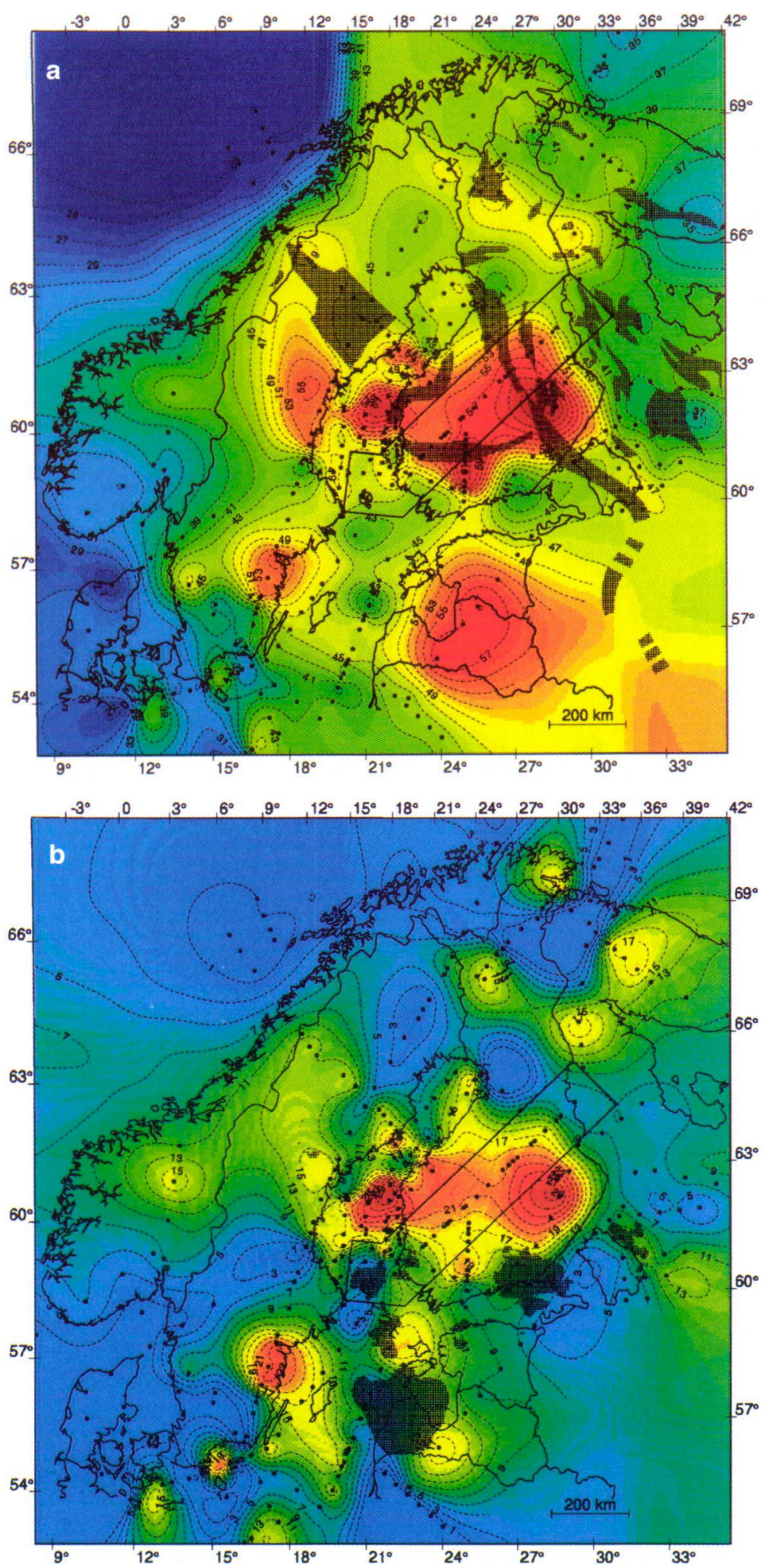

Fig. 3. (a) Crustal thickness and crustal conductors in Fennoscandia. Contours represent depths to Moho $(\mathrm{km})$ obtained from refraction seismic studies. Moho depths are interpolated from $2 D$ velocity models at sites shown as black dots. Dark brown areas indicate exposed parts of crustal conductors revealed by magnetometer and airborne electromagnetic data from the central and northeastern parts of the shield; no data are available from the southwestern part of the shield. The GGT/SVE$K A$ transect is outlined as a polygon. (b) Thickness of the lowermost high-velocity crustal layer. Contours represent thickness $(\mathrm{km})$ of the $7.0-7.7 \mathrm{~km} / \mathrm{s}$ layer. Thickness values are interpolated from $2 D$ velocity models at sites shown as black dots. Dark brown areas show rapakivi intrusions. The GGT/SVEKA transect is outlined by a polygon. Original references to the data used to compile the maps and to other details can be found in Korsman et al. (1999). 
of the Svecofennian Orogen have notably greater thickness (dominant thickness in average $55 \mathrm{~km}$ ) indicating that the crust does not always attain a "normal" thickness of ca. $40 \mathrm{~km}$ but may remain much thicker. Orogenic collapse, as a mechanism for producing normal (thinned) crust, was apparently inhibited in these areas and isostatic balance was achieved by density variations within the crust.

3 - Crust was thickened tectonically and by magmatic under- and intraplating. Tectonic thickening involved both under- and overthrusting. The presence of the thick high-velocity lower crustal layer indicates magmatic under- and intraplating.

4 - The thick Svecofennian crust has been preserved, because its density was increased by magmatic intra- and underplating. The entire Svecofennian crust equilibrated soon after magmatic underplating.

5 - Mafic high-velocity deep crustal layer was formed at several phases including the Palaeoproterozoic pre-Svecofennian extension of the Archaean crust, the formation of the Svecofennian island arc systems in subductions, the Svecofennian post-collisional underplating caused by mantle upwelling and melting of the lower crust, and the Subjotnian extension associated with the rapakivi magmatism.

6 - High metamorphic temperatures in the Svecofennian Orogen were caused by magmatic underplating between 1.885 and $1.800 \mathrm{Ga}$. Extension started soon after subduction and thickening of the crust. This extensional phase, however, did not thin the Svecofennian crust because a continuous push from southwest in ongoing accretionary processes prohibited a true collapse of the crust.

7 - In general, the large-scale architecture of the crust as imaged today have resulted from several tectonic processes that affected the whole crust. In the Svecofennides, the thickest crust was formed during the Palaeoproterozoic Svecofennian orogeny whereas the regions of thinner crust were formed during the Subjotnian extension. Similarly, the thinner parts of the Archaean Karelian Province represent Palaeoproterozoic pre- and post-Svecofennian extension, whereas the thickest parts, primarily along the craton margin, are Palaeoproterozoic Svecofennian. The latter implies that the current Moho boundary beneath the Archaean crust is likely Palaeoproterozoic in age in both regions.

Original results of the GGT/SVEKA work have been published in separate articles and in special volumes associated with the GGT/SVEKA Project (Appendix 1). This Bulletin, published by the Geological Society of Finland, is just one example of the special volumes. Major scientific results of the GGT/SVEKA work has been published by Korsman et al. (1999). Final maps and an explanatory text including a complete list of references to original work and data sources can be found in Korsman et al. (in print).

The GGT/SVEKA Project was participated by nearly all geoscientific organizations in Finland: Geological Survey of Finland, Espoo and Kuopio; Department of Geology at the University of Helsinki, Institute of Seismology at the University of Helsinki, Institute of Geology and Mineralogy at the University of Turku, Geological Department at Åbo Akademi, and the Institute of Geosciences at the University of Oulu. Many researchers outside from Finland have helped us in the course of the GGT/SVEKA work.

ACKNOWLEDGEMENTS. Besides the participating organizations, the GGT/SVEKA Project has been supported by the Academy of Finland, Finnish Cultural Foundation, and Outokumpu Company. Maps and the compilation of data and models of the GGT/SVEKA Project were evaluated by Dr. Angela Jayko (Chairman of the international GGT Project, US Geological Survey) and by professors Hans-Jorgen Goetze (former chairman of the GGT Project, Free University of Berlin) and Carl Ehlers (Åbo Akademi).

\section{REFERENCES}

Goetze, H.-J. \& Monger, J.W.H. 1992. Global Geoscience Transects Project: Achievements and Future Goals. Episodes 14 (2), 131-138.

Goetze, H.-J. \& Williams, R.T. 1993. Digitization of maps and associated geoscience data: guidelines for Global Geoscience Transects. International Lithosphere Program and American Geophysical Union, Washington, D.C., USA, Publications 239. 35 p. 
Korja, T. \& Korsman, K. 1993. Global Geoscience Transects (GGT) -hankkeen tutkimukset Suomessa. In: Mertanen, S., Laiho, A. \& Tattari, S. (eds.) 1993. XVI Geofysiikan Päivät - Kaukokartoituksen Päivät, 11.12.5.1993, Espoo. Helsinki: Geofysiikan Seura, Fotogrammetrian ja Kaukokartoituksen Seura, 35-40.

Korsman, K., Korja, T., Pajunen, M., Virransalo, P. \& the GGT/SVEKA Working Group 1999. The GGT/SVEKA Transect: Structure and evolution of the continental crust in the Paleoproterozoic Svecofennian Orogen in Finland. International Geology Review 41, 287-333.

Korsman, K., Korja, T. \& the GGT/SVEKA Working Group (in print). Global Geoscience Transect, \#23, GGT/SVEKA: Archaean Kuhmo region - Mesoproterozoic Åland Rapakivi, Finland, Northern Europe. Geological Survey of Finland, Special Paper (three map sheets and explanatory text of sheets).

\section{Appendix 1: Articles related with the GGT/ SVEKA project.}

\section{Proceedings and compilations:}

Papunen, H. (ed.) 1992. Raportti Suomen GGT-hankkeen työkokouksesta. Turku 14.-15.4.1992. University of Turku, Finland, Institute of Geology and Mineralogy, Publication No. 31. 65 p.

Ekdahl, E. \& Autio, S. (eds.) 1996. Global Geoscience Transect / SVEKA - Proceedings of the Kuopio Seminar, Finland, 25.-26.11.1993. Geological Survey of Finland, Report of Investigation 136. 62 p.

Kontinen, A. \& Paavola, J. Svecokarelian (Palaeoproterozoic) tectono-thermal effect on the Archaean bedrock of North Karelia, eastern Finland, 7-8.

Kähkönen, Y. Stratigraphy and evolution of the Palaeoproterozoic supracrustal rocks in the Tampere area, southern Finland: a preliminary review, 9-12.

Ekdahl, E. The evolution and metallogenesis of the Raahe-Ladoga Zone, 13-17.

Korja, A. \& Heikkinen, P.J. Extensional structures of southwestern Finland based on the BABEL reflection results, 19-22.

Kukkonen, I.T. Temperature and heat flow density in the bedrock on the GGT/SVEKA transect, 23-30.

Korja, T., Hjelt, S.-E., Kaikkonen, P., Pernu, T., Salmirinne, H. \& Tiikkainen, J. Geoelectric studies in the Fennoscandian Shield and along the GGT/SVEKA transect, 31-48.

Pesonen, L.J. \& Mertanen, S. The drift of Fennoscandia in the light of palaeomagnetism with examples from the Finnish GGT/SVEKA transect, 49-54.

Virransalo, P. The GGT/SVEKA transect digitization and the format for digitized information, 55.

Yliniemi, J., Jokinen, J. \& Luukkonen, E. Deep structure of the earth crust along the GGT/SVEKA transect extension to northeast, 56 .
Lahtinen, R., Nironen, M. \& Virransalo, P. Results of preliminary studies of the Central Finland Granitoid Complex, 57.

Kontinen, A. \& Peltonen, P. Petrology of the mantle section of the Jormua Ophiolite, NE Finland, 58-59.

Pajunen, M. Kyanite-chlorite-cordierite rock - a Palaeoproterozoic overprint on Archaean tonalitic gneisses, 60.

Luosto, U. Seismic studies on lithospheric structure along the GGT/SVEKA transect - a review, 61 .

Korsman, K., Korja, T. \& the GGT/SVEKA Working Group (in print). Global Geoscience Transect, \#23, GGT/ SVEKA: Archaean Kuhmo region - Mesoproterozoic Åland Rapakivi, Finland, Northern Europe. Geological Survey of Finland, Special Paper (three map sheets and explanatory text of sheets)

Idman, H. Lithological data, 2 p.

Vaasjoki, M. Isotope geological data, 2 p.

Hölttä, P. \& Pajunen, M. Metamorphic data, 2 p.

Elo, S. Gravity data, 2 p.

Kurimo, M. \& Ruotoistenmäki, T. Magnetic data, 2 p.

Luosto, U. Seismic data, 3 p.

Kukkonen, I.T. Thermal data, 3 p.

Korja, T. \& Lerssi, J. Geoelectromagnetic data, 3 p.

Pesonen, L.J., Leino, M.A.H. \& Mertanen, S. Palaeomagnetic data, $3 \mathrm{p}$.

Säävuori, H. Petrophysical data, 2 p.

Korja, T. Major geophysical features along the GGT/ SVEKA transect, $19 \mathrm{p}$.

Korsman, K. General geological features and tectonometamorphic evolution, $10 \mathrm{p}$.

Luukkonen, E. Meso - Neoarchaean in the northeastern end of the transect, $3 \mathrm{p}$.

Pajunen, M. Palaeoproterozoic overprint on the Archaean crust, 2 p.

Kontinen, A. \& Peltonen, P. Jormua Ophiolite, 3 p.

Tuisku, P. \& Kontinen, A. Kainuu Schist Belt, 5 p.

Hölttä, P., Huhma, H. \& Paavola, J. Temporal and metamorphic development of the Archaean Iisalmi Block, 4 p.

Ekdahl, E., Lukkarinen, H., Luukas, J., Korja, T., Ruotoistenmäki, T., Tervo, T. \& Yliniemi, J. Boundary zone between the Archaean Karelian Province and the Palaeoproterozoic Svecofennian Orogen, 3 p.

Nironen, M. Central Finland Granitoid Complex, 2 p.

Kähkönen, Y. Palaeoproterozoic Tampere-Vammala Arc System, southern Finland, 4 p.

Pihlaja, P. Jotnian Sandstone Formation, 3 p.

Korja, A. \& Rämö, O.T. Rapakivi Granite Plutons, 6 p.

Väisänen, M. \& Hölttä, P. Lithology, deformation and metamorphism of SW Finland, 3 p.

\section{Separate articles and abstracts:}

Elo, S. 1994. Preliminary notes on gravity anomalies and mafic magmatism in Finland. In: Pajunen, M. (ed.) High temperature-low pressure metamorphism and deep crustal structures. Meeting of IGCP project 304 'Deep Crus- 
tal Processes' in Finland, September 16-20, 1994. Geological Survey of Finland, Guide 37, 49-55.

Elo, S. \& Virtanen, H. 1994. Finnish GGT Project: Gravity maps and data for the Finnish GGT/SVEKA project. Geological Survey of Finland, unpublished report. 28 pages + 1 MS-DOS diskette.

Hölttä, P. 1995. Contact metamorphism of the Vaaraslahti pyroxene granitoid intrusion in Pielavesi, Central Finland. Geological Survey of Finland, Bulletin 382, 27-79.

Hölttä, P. 1997. Geochemical characteristics of granulite facies rocks in the Archaean Varpaisjärvi area, central Fennoscandian Shield. Lithos, 40, 31-53.

Jokinen, J. 1997. GGT-hanke, Keski-Suomen granitoidialueen painovoimatulkinta. Geological Survey of Finland, unpublished report Q21/997/1. 11 p.

Kähkönen, Y., Lahtinen, R. \& Nironen, M. 1994. Palaeoproterozoic supracrustal belts in southwestern Finland. In: Pajunen, M. (ed.) High temperature-low pressure metamorphism and deep crustal structures. Meeting of IGCP project 304 'Deep Crustal Processes' in Finland, September 16-20, 1994. Geological Survey of Finland, Guide 37, 43-48.

Kilpeläinen, T., Korikovsky, S., Korsman, K. \& Nironen, M. 1994. Tectono metamorphic evolution in the Tampere-Vammala area. In: Pajunen, M. (ed.) High temperature-low pressure metamorphism and deep crustal structures. Meeting of IGCP project 304 'Deep Crustal Processes' in Finland, September 16-20, 1994. Geological Survey of Finland, Guide 37, 27-34.

Kilpeläinen, T. 1998. Evolution and 3D modelling of structural and metamorphic patterns of the Palaeoproterozoic crust in the Tampere-Vammala area, southern Finland. Geological Survey of Finland, Bulletin 397. 124 p.

Koistinen, T., Klein, V., Koppelmaa, H., Korsman, K., Lahtinen, R., Nironen, M., Puura, V., Saltykova, T., Tikhomirov, S. \& Yanovskiy, A. 1996. Paleoproterozoic Svecofennian orogenic belt in the surroundings of the Gulf of Finland. In: Koistinen, T.J. (ed.) Explanation to the map of Precambrian basement of the Gulf of Finland and surrounding area $1: 1$ mill. Geological Survey of Finland, Special Paper 21, 21-57.

Korja, A., Korja, T., Luosto, U. \& Heikkinen, P. 1993. Seismic and geoelectric evidence for collisional and extensional events in the Fennoscandian Shield - implications for Precambrian crustal evolution. Tectonophysics 219, 129-152.

Korja, A. \& Korja, T. 1997. Crustal structure in the Fennoscandian Shield. In: Rutland, R.W.R. \& Drummond, B.J. (eds.) Palaeoproterozoic Tectonics and Metallogenesis: Comparative analysis of parts of the Australian and Fennoscandian Shields. Australian Geological Survey Organisation, Record 1997/44, 67-72.

Korja, T. \& Korsman, K. 1993. GGT and SVEKA 19921996. GISK/SVEKA-transektin tutkimukset GGT-hankkeessa. Geological Survey of Finland, unpublished report K/10/-93/2. 22 p.

Korja, T. \& Koivukoski, K. 1994. Magnetotelluric investigations along the SVEKA profile in central Fenno- scandian Shield, Finland. Geophysical Journal International 116, 173-197.

Korja, T., Luosto, U., Korsman, K. \& Pajunen, M. 1994. Geophysical and metamorphic features of Palaeoproterozoic Svecofennian orogeny and Palaeoproterozoic overprinting on Archaean crust. In: Pajunen, M. (ed.) High temperature-low pressure metamorphism and deep crustal structures. Meeting of IGCP project 304 'Deep Crustal Processes’ in Finland, September 16-20, 1994. Geological Survey of Finland, Guide 37, 11-20.

Korja, T. 1996. Electrical conductivity of the lithosphere - implications for the evolution of the Fennoscandian Shield. Geophysica 33, 15-48.

Korja, T. \& Hjelt, S.-E. 1998. The Fennoscandian Shield: A treasury box of deep electromagnetic studies. In: Roy, K.K., Verma, S.K. \& Mallick, K. (eds.) Deep Electromagnetic Exploration. New Delhi, India: Narossa Publishing House, 31-73.

Korsman, K. 1996. Global Geoscience Transects Project in Finland. In: The $30^{\text {th }}$ International Geological Congress 4.-14.8.1996, Beijing, China. Abstracts. Vol. 1, p. 139.

Korsman, K. \& Koistinen, T. 1998. Suomen kallioperän yleispiirteet. In: Lehtinen, M., Nurmi, P. \& Rämö T. (eds.) Suomen Kallioperä. Helsinki: Suomen Geologinen Seura r.y., 93-103.

Korsman, K., Hölttä, P. \& Pajunen, M. 1996. Tectonometamorphic evolution of the Paleoproterozoic Svecofennian orogeny in Finland. In: The $30^{\text {th }}$ International Geological Congress 4.-14.8.1996, Beijing, China. Abstracts. Vol. 2, p. 583.

Korsman, K., Koistinen, T., Kohonen, J., Ekdahl, E., Honkamo, M., Idman, H. \& Pekkala, Y. et al. 1997. Suomen kallioperäkartta - Bedrock Map of Finland 1: 1000 000. Espoo: Geological Survey of Finland.

Korsman, K., Korja, T. \& Virransalo, P. 1997. Global geoscience transect programme in Finland: The GGT/ SVEKA transect. In: Dawei, H. (ed.) Structure of the Lithosphere and Deep Processes. Proceedings of the $30^{\text {th }}$ International Geological Congress 4.-14.8.1996, Beijing, China. Vol. 4. Utrecht: VSP BV, 77-90.

Korsman, K., Korja, T., Pajunen, M., Virransalo, P. \& the GGT/SVEKA Working Group 1999. The GGT/ SVEKA Transect - Structure and Evolution of the Continental Crust in the Palaeoproterozoic Svecofennian Orogen in Finland. International Geology Review 41, 287-333.

Kousa, J., Marttila, E. \& Vaasjoki, M. 1994. Petrology, geochemistry and dating of Paleoproterozoic metavolcanic rocks in the Pyhäjärvi area, central Finland. In: Nironen, M. \& Kähkönen, Y. (eds.) Geochemistry of Proterozoic supracrustal rocks in Finland. IGCP Project 179 Stratigraphic methods as applied to the Proterozoic record and IGCP Project 217 Proterozoic geochemistry. Geological Survey of Finland, Special Paper 19, 7-27.

Kukkonen, I.T. 1998. Temperature and heat flow density in a thick cratonic lithosphere: the SVEKA transect, cen- 
tral Fennoscandian Shield. Journal of Geodynamics 26, 111-136.

Lahtinen, R. 1994. Crustal evolution of the Svecofennian and Karelian domains during 2.1-1.79 Ga, with special emphasis on the geochemistry and origin of 1.93-1.92 $\mathrm{Ga}$ gneissic tonalites and associated supracrustal rocks in the Rautalampi area, central Finland. Geological Survey of Finland, Bulletin 378. 128 p.

Lahtinen, R. \& Korhonen, J.V. 1996. Comparison of petrophysical and rock geochemical data in the TampereHämeenlinna area, southern Finland. Geological Survey of Finland, Bulletin 392. 45 p.

Lahtinen, R. \& Huhma, H. 1997. Isotope and geochemical constrains on the evolution of the 1.93-1.79 Ga Svecofennian crust and mantle in Finland. Precambrian Research $82,13-34$.

Luosto, U., Grad, M., Guterch, A., Heikkinen, P., Janik, T., Komminaho, K., Lund, C.-E., Thybo, H. \& Yliniemi, J. 1996. Crustal Structure along the SVEKA'91 Profile in Finland. In: Proceedings of the XXIV General Assembly of the European Seismological Commission, 19.-24.9.1994, Athens, 974-983.

Nironen, M. 1997. The Svecofennian Orogen: a tectonic model. Precambrian Research 86, 21-44.

Pajunen, M., Korja, T., Korsman, K., Virransalo, P. \& the GGT/SVEKA Working Group 1997. Introduction to the Finnish Precambrian with special emphasis on the Palaeoproterozoic Svecofennian Orogeny. In: Rutland, R.W.R. \& Drummond, B.J. (eds.) Palaeoproterozoic Tectonics and Metallogenesis: Comparative analysis of parts of the Australian and Fennoscandian Shields. Australian Geological Survey Organisation, Record 1997/ 44, 91-94

Pajunen, M., Korja, T., Korsman, K., Virransalo, P. \& the GGT/SVEKA Working Group 1997. The Global Geoscience Transect GGT/SVEKA in Finland: crustal model for the Svecofennian orogeny. In: Hölttä, P. (ed.) Mineral equilibria and databases. Geological Survey of Finland, Guide 46, p. 54.

Pajunen, M., Korja, T., Korsman, K., Virransalo, P. \& the GGT/SVEKA Working Group 1997. The Global Geoscience Transect GGT/SVEKA in Finland - crustal model for the Svecofennian orogeny by linking geological and geophysical data. In: Korhonen, J. (ed.) Petrophysics in Potential Field Interpretation. The First Workshop for the Finnish Geophysical Crustal Model Program, 1516 August 1997, Espoo, Finland. Abstracts. Espoo: Geological Survey of Finland, p. 41

Peltonen, P. 1994. Mafic-ultramafic intrusions in southwestern Finland. In: Pajunen, M. (ed.) High temperaturelow pressure metamorphism and deep crustal structures. Meeting of IGCP project 304 'Deep Crustal Processes' in Finland, September 16-20, 1994. Geological Survey of Finland, Guide 37, 57-60.

Peltonen, P. 1995. Petrogenesis of ultramafic rocks in the Vammala Nickel Belt: implications for crustal evolution of the early Proterozoic Svecofennian arc terrane. Lithos 34, 253-274.

Peltonen, P., Kontinen, A. \& Huhma, H. 1996. Petrology and geochemistry of metabasalts from the 1.95 Ga Jormua Ophiolite, northeastern Finland. Journal of Petrology 37, 1359-1383.

Pietikäinen, K.J. 1994. The geology of the Paleoproterozoic Pori shear zone, southwestern Finland, with special reference to the evolution of veined gneisses from tonalitic protoliths. Unpublished $\mathrm{Ph}$.D. dissertation, Michigan Technological University, Houghton, MI, USA. 150 p.

Ruotoistenmäki, T. 1996. A schematic model of the plate tectonic evolution of Finnish bedrock. Geological Survey of Finland, Report of Investigation 133. 23 p.

Vaasjoki, M., Huhma, H. \& Karhu, J. 1994. Evolution of the continental crust in Finland with special reference to the Svecofennian orogeny. In: Pajunen, M. (ed.) High temperature-low pressure metamorphism and deep crustal structures. Meeting of IGCP project 304 'Deep Crustal Processes' in Finland, September 16-20, 1994. Geological Survey of Finland, Guide 37, 21-26.

Väisänen, M., Hölttä, P., Rastas, J., Korja, A. \& Heikkinen, P. 1994. Deformation, metamorphism and deep structure of the crust in Turku area, southwestern Finland. In: Pajunen, M. (ed.) High temperature-low pressure metamorphism and deep crustal structures. Meeting of IGCP project 304 'Deep Crustal Processes' in Finland, September September 16-20, 1994. Geological Survey of Finland, Guide 37, 35-41. 